\title{
GELCASTING: FROM LABORATORY DEVELOPMENT TOWARD INDUSTRIAL PRODUCTION.
}

\author{
Ogbemi O. Omatete and Mark A. Janney \\ Oak Ridge National Laboratory, P. O. Box 2008, Oak Ridge, TN 37831-6087, USA.
}

\begin{abstract}
Gelcasting, a ceramic forming process, was developed to overcome some of the limitations of current complex-shape forming techniques such as injection molding and slip casting while reducing the costs of shaping advanced ceramics. Gelcasting is based on the separation of the mold filling step from the setting step in these forming processes by utilizing the polymerization of organic monomers into a chemical gel which holds the ceramic powder in place after the mold is filled. The simplicity of the process has attracted industrial partners and by collaboration between them and the developers, the process is being advanced from the laboratory toward industrial production.
\end{abstract}

\section{Introduction}

The advantages of advanced ceramics over metals in harsh environments have lead to extensive research in the last three decades to improve their reliability. Although the research resulted in the development of toughened, more reliable ceramics, the production cost of ceramic parts remained prohibitive. Not only was the high purity ceramic powder used expensive, but the shaping process to produce the desired parts was also costly. Consequently, about a decade ago, as part of the ceramic program at the Oak Ridge National Laboratory (ORNL), a project was initiated to develop a low-cost, high-reliability ceramic forming process. The desired process should be capable of producing near-net-shape, complex shapes, and large sections. In addition, it should be scalable to high-volume production and have high yields.

The initial step was to evaluate the current methods at the time for making complex-shaped advanced ceramics. These were and are still machining, injection molding, and slip casting or pressure casting. Machining of green and fired parts can used to produce any desired shape but is very expensive especially for fired parts and where possible, should be avoided or minimized. Injection molding is the major shape forming process but has the following drawbacks: long binder removal times (up to 7 days), thick section cracking, size limitations $(<3 \mathrm{~cm}$ diameter), and defects such as knit lines, short shots, flashing, sink marks, and thermal strains. For larger sizes, slip casting or pressure casting is used. Slip casting is a slow process with long forming times (hours), density variations, and is labor intensive. Pressure casting is a modification of slip casting to improve the rate of casting.

Injection molding, slip casting and pressure casting are all based on the flow of a fluid slurry to fill the mold, followed by a process to harden the slurry. The problems with injection molding result because the fluid flow to fill the mold and the hardening of the slurry are based on competitive and often interfering heat transfer steps. Similarly, the density variation in both slip and pressure casting occur because the mold filling and hardening process are not separated. What is needed, therefore, is a process that separates these two steps and also facilitates the removal of vehicle that nomise tho romomin n..... 


\section{DISCLAMMER}

Portions of this document may be illegible in electronic image products. Images are produced from the best available original document. 
Theoretically, the hardening or setting mechanism can accomplished by processes such as heterocoagulation, controlled flocculation (dispersant deactivation or flocculant activation), phase separation or gelling binders. Gelcasting which was the process developed at the Oak Ridge National Laboratory, is based on gelling binders. However, gelcasting utilizes chemical gels rather than physical gels which have been applied to injection molding (Rivers process, AlliedSignal aqueous injection molding).

\section{New process-Gelcasting}

Gelcasting is a forming process in which a concentrated slurry of ceramic powder in a solution of organic monomers is poured into a mold and then polymerized to form a green body in the shape of the mold cavity. The monomer solution provides a low viscosity vehicle to transport the fluid slurry into the mold and the polymer gel holds the ceramic powder in the desired shape. The process separates the mold filling step from the setting of the mix, and because it is a free-radical chain polymerization process, the setting is very rapid. The vehicle removal is by drying followed by pyrolysis. The part is then fired to densify it. Gelcasting has thus overcome the major drawbacks of both injection molding and slip and pressure casting by separating the competing steps.

The initial gelcasting process was developed by dissolving multifunctional acrylate monomers in organic solvents $[1,2]$. The ceramic powder was then slurried in this organic solution and cast into a mold. Thus, the gelcasting concept was successfully demonstrated. However, in anticipation of environmental problems and the additional costs of the removal of the organic solvent, and because most ceramists prefer to work in water, an effort was begun to use aqueous solvent. The initial development in aqueous system was with acrylate monomers and these systems met with limited success. This was followed by the use of acrylamide monomer and the results were surprisingly excellent. The initial detailed studies were done using alumina [3]. However, several complex and simple shapes have been gelcast as monolithics or composites using a variety of ceramic powders. The acrylamide system established aqueous gelcasting as a major advanced ceramic forming process [2] and demonstrated some its advantages:

Generic, adaptable to a variety of ceramic powders

Produces near-net-shape parts

Produces complex shapes, limited only by mold design

Uses wax, plastic, glass, or metal molds

Produces durable, readily machinable dried parts

It is simple and presents minimal deviation from traditional ceramic forming (See Figure 1).

Development toward industrial production

Although acrylamide gels have been used for decades in biology for gel electrophoresis in DNA and other analyses, the acrylamide monomer is neurotoxic. Because of this, many ceramic companies who were interested in the process became cautious. Consequently, less toxic monomers were developed and are now being used; methacrylamide has now replaced acrylamide. Several companies signed CRADAs (Cooperative Research and Development Agreement) with ORNL to investigate gelcasting. These CRADAs have advanced the development of the gelcasting process and have shown that gelcasting does not affect the properties of the fired ceramic part. The microstructures of ceramic parts formed by gelcasting are not different from those made by other forming methods. The collaborative

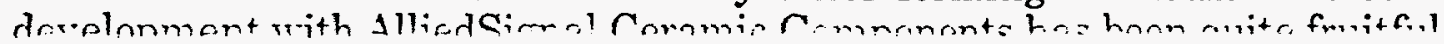




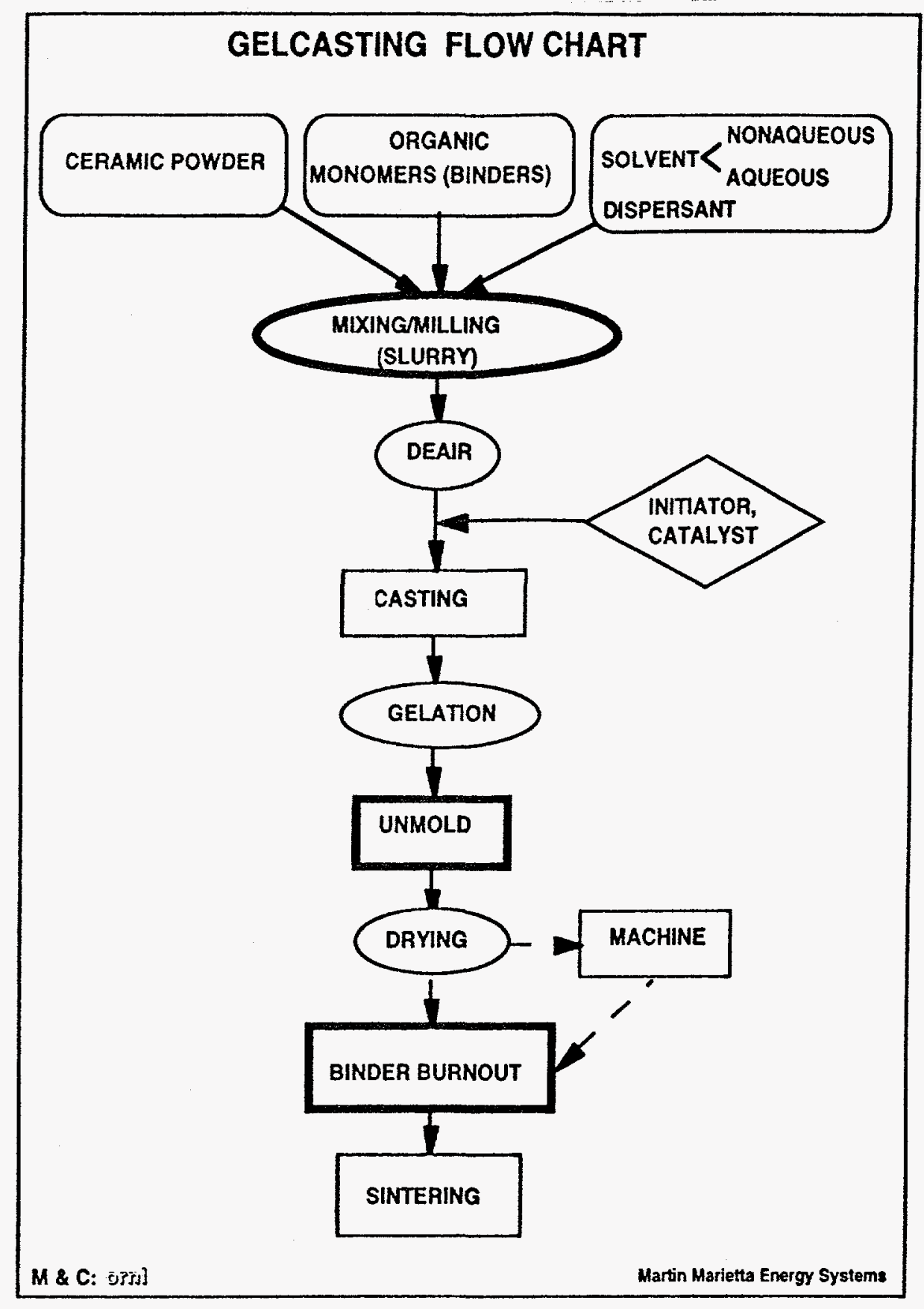

Figure 1: Gelcasting Flow Chart (typical slip processing).

They have shown that whereas $\mathrm{Si}_{3} \mathrm{~N}_{4}$ parts produced by gelcasting and slip casting have similar strength and Weibull modulus (slipcast: $\sigma=954 \mathrm{MPa}, \mathrm{m}=18.9$, gelcast: $\sigma=1017 \mathrm{MPa}, \mathrm{m}=15.5$ ); gelcast parts have significantly less density variation. Over a $50 \mathrm{~mm} \times 76 \mathrm{~mm} \times 38 \mathrm{~mm}\left(2^{\prime \prime} \times 3 " \times 1.5\right.$ ") $\mathrm{Si}_{3} \mathrm{~N}_{4}$ plate, the density variation for the slipcast plate was $2.8 \%$ compared to just $0.8 \%$ for the gelcast plate. In anticipation of industrial-level production of ceramic parts by gelcasting, AlliedSignal Ceramic Component invited one of the researchers in gelcasting to spend three months at their company under a project of the Advanced Technology 
kilogram batches of their $\mathrm{Si}_{3} \mathrm{~N}_{4}$ formation instead of small batches that were used in the research laboratory. By using Taguchi statistical methods and optimizing the green strength of dried gelcast parts, they developed $\mathrm{Si}_{3} \mathrm{~N}_{4}$ gelcasting slurries for producing turbine rotors. During the three months' interaction, they demonstrated that the dried gelcast $\mathrm{Si}_{3} \mathrm{~N}_{4}$ part is strong enough to withstand greenmachining. Thus, although gelcasting is primarily a near-net-shape process, more complex shapes can be produced as needed by green-machining of the dried part.

AlliedSignal Ceramic Components was impressed with the simplicity and robustness of the gelcasting process and continues to work with it. They have licensed the process for making advanced $\mathrm{Si}_{3} \mathrm{~N}_{4}$ components of various shapes and for different applications. They plan to use gelcast parts in some of their initial tests, preparatory to trials for more rigorous applications. LoTEC, Inc. has also licensed the gelcasting process for the forming of complex shaped parts from low thermal expansion (NZP) ceramics. These ceramics have potential uses as automotive exhaust portliners. ORNL has continued to work on CRADAs with other companies to determine if the process matches their needs. Consequently, ORNL believes that gelcasting is gradually moving toward industrial applications and production.

\section{References}

1. M. A. Janney, "Method for Forming Ceramic Powders into Complex Shapes," U.S. Patent No. 4,894,194, January 16, 1990.

2. O. O. Omatete, M. A. Janney \& R. A. Strehlow, "Gelcasting- A New Ceramic Forming Process," Ceramic Bulletin, 70 [10], Oct 1991.

3. A. C. Young, O. O. Omatete, M. A. Janney, \& P. A. Menchhofer, "Gelcasting of Alumina," J. Am. Ceram. Soc., 74 [3] 612-18 (1991).

Research sponsored by the U.S. Department of Energy, Assistant Secretary for Energy Efficiency and Renewable Energy, Office of Transportation Technologies, as part of the Ceramic Technology Project of the Propulsion System Materials Program, under contract DE-AC05-840R21400 with Martin Marietta Energy Systems, Inc.

\section{DISCLAIMER}

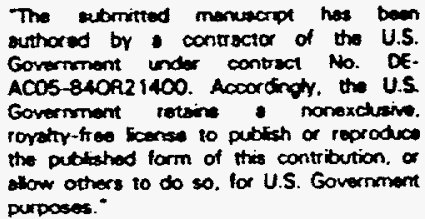

This report was prepared as an account of work sponsored by an agency of the United States Government. Neither the United States Government nor any agency thereof, nor any of their employees, makes any warranty, express or implied, or assumes any legal liability or responsibility for the accuracy, completeness, or usefulness of any information, apparatus, product, or process disclosed, or represents that its use would not infringe privately owned rights. Reference herein to any specific commercial product, process, or service by trade name, trademark, manufacturer, or otherwise does not necessarily constitute or imply its endorsement, recommendation, or favoring by the United States Government or any agency thereof. The views and opinions of authors expressed herein do not necessarily state or reflect those of the United States Government or any agency thereof. 